\title{
Tangible Religion: Amulets, Illnesses, and the Demonic Seven Sisters
}

Rudolf simek

University of Bonn

It is a well-known fact within Medieval studies that in Western Europe in the Middle Ages there existed, side by side, three major strategies of coming to terms with illnesses:

Firstly, what we today would consider proper medical therapy, in its many variants from traditional monastic medicine (by the infirmarii) to itinerant barber surgeons (medici) to academic medical science (phisici) as practised within and without the Salernitan school. Medical handbooks in manuscript form, containing collections of active ingredients (simplicia) and prescriptions for particular ailments (indicationes) as well as rules on dietetics and prognostics testify to this tradition even in Old Norse vernacular texts.

Secondly, by taking recourse to miraculous divine help, usually in the form of asking the saints for intercession on the behalf of the patient or his kin, whether by prayer alone or the promise of votive gifts, resulting in the miraculous recovery of the patient at least in the many successful cases reported and handed down in hagiographic literature, usually in the miracle collections tied to the lives of particular saints, certainly not as case histories on the recovery of particular patients and even less connected with particular illnesses - unless the saint in question was known to "specialise" in certain medical problems, such as St. Margaret for difficult births and St. Blaise for throat illnesses, to name but two of many.

Thirdly, by taking resort to religio-magical practises, such as magical charms, amulets, and rituals. Although all of these were

How to cite this book chapter:

Simek, R. 20I9. Tangible Religion: Amulets, Illnesses, and the Demonic Seven Sisters. In: Wikström af Edholm, K., Jackson Rova, P., Nordberg, A., Sundqvist, O. \& Zachrisson, T. (eds.) Myth, Materiality, and Lived Religion: In Merovingian and Viking Scandinavia. Pp. 375-395. Stockholm: Stockholm University Press. DOI: https://doi.org/IO.I6993/bay.m. License: CC-BY. 
expressly condemned not only in the ecclesiastical writings of the missionary period - which considered them to be remnants of the heathen past - but also in penitential handbooks throughout the Middle Ages. Many of these practises may indeed have their roots in the pagan pre-Christian Germanic religion, but there is also much interference from much older Mediterranean and Near Eastern magical methods, that merged into what we now term typical Medieval Popular Religion.

The present paper only concerns itself with the third method of fighting illnesses, and within this group only with apotropaic measures to be found on amulets (ligamina, ligamenta, obligamenta, ligaturae).

When, in previous papers, ${ }^{\mathrm{I}}$ I was trying to work out what role the álfar had in the Scandinavian medieval popular religion (- who were occasionally, but rarely seen as having medical powers in the Icelandic sagas), ${ }^{2}$ and had to come to the conclusion that by the $\mathrm{II}^{\text {th }}-\mathrm{I} 4^{\text {th }}$ centuries, alfar (called elvos, elvas or similar in their Latinized form) were considered demons of illness, and the charms which preserve such identifications are found on lead amulets meant to conjure and thus avert the doings of these demons, thus removing the source of the illness. This throws light on an instance in Kormáks saga: the magical practise suggested here by an old witch thus did not attempt to call on the álfar/demons to heal the person in question, but rather tempt/bribe the demons to remove themselves as being the source of the illness. In this particular instance, the passage implies that: álfar are subterranean, that they live in (grave?)-mounds and have supernatural powers related to illnesses and that they can be influenced through rituals / magic practices.

But this is the only text I know of this particular type, although there may be others in hagiographic sagas. In other Old Norse sources, especially in Eddic poetry, the álfar were not primarily considered to be demonic at first sight. They are to the largest extent found in alliterative formulae, such in álfar ok cesir, or álfar ok oesir ok visir vanir, and unless one would like to claim that the demonization of the old Scandinavian gods had progressed quite far at the time of the composition of Eddic poetry, we have to assume that the álfar stood for a mythological race whose exact identification is no longer possible, but was not synonymous with that of the cesir. 
However, it is not unlikely that they were considered to be connected with the world of spirits, and perhaps also directly connected with the dead, but in any case, to be one of the subterranean races.

In the present paper, I am not concerned with the identification and the nature of the álfar, but rather with the connection of álfar and other spirits to illnesses in popular religion, and mainly on medieval amulets.

Of these, an increasing number of textual amulets have been found in recent years, most of them made from thin lead sheets, although a few silver and copper ones are known, too. ${ }^{3}$ Imer $^{4}$ is able to list 30 amulets with text for Norway, 20 for Sweden and over a Ioo for Denmark. In addition to that, a steadily increasing number of amulets are found in Germany, especially in the eastern part of the country. ${ }^{5}$ As far as I can make out, the majority of Danish amulets are executed in runes, the German ones mainly in Latin or cryptography. To these we may add some I 8 Norwegian and two Swedish lead mortuary crosses, ${ }^{6}$ of which those with text on them seem always to be scratched in runes rather than Roman letters. ${ }^{7}$ Despite the fact that most of the Danish amulets are either illegible, fragmentary, or cannot be opened without damage to the object, it is noticeably that those with longer texts tend to be executed in Roman letters (the exceptions being the Odense and the Blæsinge amulets), whilst the shorter and/or unintelligible ones are predominantly in runes.

Apart from those amulets which carry an explicitly apotropaic text, conjuring spirits to prevent an illness, the amulets which carry either the full text of the beginning of the gospel according to John, ${ }^{8}$ such as the Randers amulet, ${ }^{9}$ or else reference to that Gospel and the very first word of it, ${ }^{10}$ such as the one from Schleswig, can also be considered to carry apotropaic messages, as is confirmed by the Codex Upsaliensis C 222 from c. I 300, which preserves a conjuration beginning

Jnitium sancti euangelij secundum iohannem. In principio erat uerbum [...] hoc erat in principio apud deum etc. Adiuro uos elphos elphorum gordin. ingordin. Cord'i et ingordin. gord'I. ${ }^{\text {I }}$

However, only the Schleswig lead tablet ${ }^{12}$ seems to combine the Gospel with a conjuration as in the Uppsala manuscript, and I 
shall not consider the amulets with the beginning of John's Gospel in the following paper, although the connection between this text and particular ailments has to date not been fully investigated. But, as Steenholt Olesen ${ }^{13}$ points out correctly: "In general, the evidence from late medieval medical books makes it clear that specific Latin phrases were used in rituals of protection and for the healing of fevers, eye diseases, boils, and so on."

Only a small number of Scandinavian Medieval amulets actually contain a direct invocation of spirits, either as álfar or demons, ${ }^{14}$ but, as this identification is beyond doubt in these cases, the use of the terms elvos, elvas and similar may simply be seen as an attempt to produce the vernacular term for demon in the otherwise Latin texts - perhaps to ensure that the demons which were being conjured understood in any case. Therefore, I shall include all texts concerned with demonic conjurations, whatever term for demons is used, and whether written in Latin letters or (very occasionally) in runes; whichever script is used, the language is Latin throughout, with only a few vernacular words interspersed and several names of mixed, but mainly Latin, Greek, or even Near Eastern provenance. Despite the above-mentioned fact that a majority of lead amulets seems to be written in runes, those relatively few that contain a legible coherent text are predominantly written in Latin. This is a point that needs stressing, because "Lead tablets with Latin inscriptions in roman letters are also known from the Danish area, but unfortunately they have not been systematically registered." Is Why this is so, and why archaeologists in Scandinavia seem to be more interested in amulets in runic script than those with Roman script one can only guess at. One may also speculate on the reasons why there are more meaningful amulets preserved in Roman script although the total number of runic ones is greater, especially as several of the shorter runic inscriptions do not seem to make sense at all or are even written in pseudo runes. ${ }^{16}$

Nearly all the amulets with longer texts I have studied not only conjure some supernatural beings, but also specify in some detail how or where the conjuration should protect the person in question, who I would like to call "the patient", as it can be assumed that these amulets were not issued primarily to healthy persons to 
protect from all eventualities - the conjurations are somewhat too specific for that - but as a means to (further) protect a sick person from further suffering, if proper medical help had either proven ineffective or else was unavailable. To gain further insight into the methods used for these apotropaic measures I shall firstly look into the types of protection from illnesses named on the amulets and secondly try to ascertain whether there is any relation between the protection requested and the types of demons conjured.

In the current investigation, I have used the following amulets:

I. The lead amulet from Blæsinge (Zealand, Sj 50), dating from any time between the $\mathrm{I} 3^{\text {th }}$ and the $\mathrm{I} 5^{\text {th }}$ century, is executed in Latin in runes and is, with roughly 500 runes, in fact the longest runic inscription found in Denmark to date.

2. The lead amulet from Viborg (Jutland, MJy 32), from I050-I300, with a short Latin text in runes which are difficult to read, but also preserves a type of Latin conjuration or prayer.

3. The lead amulet from Romdrup (near Aalborg, Jutland), dating to around I200, executed in Latin script like all the following texts.

4. A newly found and not as yet properly published lead amulet from Møllergarde, Svendborg, also roughly dated to the High Middle Ages, in Latin letters.

5. The lead amulet from Schleswig from either the $\mathrm{II}^{\text {th }}$ or early $I 2^{\text {th }}$ century containing the longest of the texts with just under 600 letters.

6. The lead amulet cross from Halberstadt (Saxony-Anhalt, Germany, dated to II42), with a Latin text only fractionally shorter than the Schleswig amulet.

Of these, the following amulets name or define the spirits that are conjured: The Blæsinge amulet names them septem sorores ... Elffrica (?), Affricea, Soria, Affoca, Affricala, the one from Romdrup eluos nel eluas aut demones, the one from Svendborg apparently more or less the same formula, the long Schleswig amulet the more comprehensive demones sive albes ac omnes 
pestes omnium infirmitatum and the one from Halberstadt the somewhat different alb(er) qui [u]ocaberis diabolus $v(e) l$ satanas, i.e. the Devil himself.

As all the amulets mentioned are conjurations, and the rest of the texts on them have much in common between them, ${ }^{17}$ it can be assumed that the terms for the spirits conjured on these amulets were, at least to some extent, interchangeable, so that we have a list of spirits called, in the latinized forms used:

Demones (pl.)

Elvae (pl. f.)

Elves (pl. m.)

Albes (pl.f. and m.?)

Pestes (omnium infirmitatum) (pl., obviously as a personification of pestis "plague": "you plagues of all illnesses")

Septem sorores (with five out of seven names)

Alber (sg. m.)

Diabolus (sg. m.)

Satanas (sg. m.)

This array of demons is, not only on the Schleswig amulet, conjured to protect someone from some harm or illness. All of the items I have selected give some indication as to the nature of the protection expected from the conjuration, so that the demons are called upon:

- On the Blæsinge tablet: ut non noceatis istam famulum Dei, neque in oculis, neque in membris, neque in medullis, nec in ullo compagine membrorum eius "that you may not harm this servant of God, neither in the eyes nor in the limbs nor in the marrow nor in any joints of the limbs".

- On the Schleswig text: ut non noceatis famulo dei neque in die nec in nocte nec in ullis horis "that you may not harm this [male] servant of God by day or by night, nor at any hours".

- On Romdrup: ut non noceatis huic famulo dei nicholao in oculis nec in capite neque in ulla compagine membrorum "that you may not harm this servant of God, Nicholas, in the eyes nor in the head nor in the joints of his limbs". 
- On Svendborg: ut non noceatis famulam dei Margaretam nec in oculis nec in aliis membris "so that you may not harm this servant of Christ, Margaret, neither in the eyes nor in other limbs [or: other parts of the body]".

- On the Halberstadt tablet: non habeas potestatem in ista [...] dere aut istum amicum dei TADO. Ne nocere possis non in die neque in nocte non in [...] su neque non bibenda neque manducando "so that you have no power over this ..... or this friend of god Tado, so that you cannot harm during the day nor by night nor drinking nor eating nor ...”.

- On the both fragmentary and badly executed Viborg amulet we can reconstruct the words: $c b$ omnis febris "from all fevers" from the runic sequence mitius( $\mathfrak{x})(\mathbf{o})$ ni fibri, although there is not enough left of the amulet to discern any conjuration, only an invocation of God, the Holy Spirit and Mary.

Of all these indications as to the nature of the illnesses meant, the most disappointing is the one on the Schleswig amulet, just asking for protection "by day and by night". However, as the beginning of the conjuration formula is very close to those on the Romdrup and Svendborg amulets, it is possible to infer what the protection was about: Both the latter ones ask for protection of the eyes and the limbs, Romdrup in addition names the head and the joints of the limbs, thus specifying the seat of the illness caused (apparently) by the "demons and elves" called upon by all three texts.

The Halberstadt text is less specific again, but the reference to "day and night" and "eating and drinking" may suggest that the devil called Alber here might have something to do with poising or spoiling of food and drink, but this if of course impossible to prove.

The most interesting information, therefore, is the one on the Blæsinge and the Romdrup texts, where "eyes nor in the limbs nor in the marrow nor in any joints of the limbs" and "in oculis nec in capite neque in ulla compagine membrorum" are referred to, as well as the new Svendborg amulet, which also seems to mention the eyes and the limbs. A quick diagnosis of an illness that causes pains in the eyes, the head, and the joints of the limbs points very 
much to a febrile infection of the influenza type, according to GPs consulted. But as mentioned before, the only fevers mentioned, namely on the Viborg amulet, we cannot, due to the fragmentary state of the piece, associate with any particular spirits. All we know is that it was used to avert fevers.

In order to ascertain which spirits are actually causing which illnesses, this leaves us with the most specific of all the known amulets, namely the Blæsinge one, which conjures the Seven Sisters in order to prevent them from doing harm "in the eyes nor in the limbs nor in the marrow nor in any joints of the limbs." This is, of course, very similar to the descriptions given on the amulets from Schleswig, Romdrup and Svendborg, but the conjuration of the Seven Sisters opens up an additional line of interpretation.

Although the Seven Sisters are, to my knowledge, not mentioned on any other amulets found to date, they do appear in several medieval manuscripts, which provide further details. Already Düwel $^{18}$ could refer to Stoklund ${ }^{\mathrm{1} 9}$ for several invocations calling upon the septem sorores, printed by Franz. ${ }^{\circ}$ The most detailed from the Codex Vaticanus Latinus 235 (fol. 44-45; I0 ${ }^{\text {th }} / \mathrm{I} \mathrm{I}^{\text {th }}$ century) reads:

Coniuro uos, frigores et febres - VII sorores sunt - siue meridianas, siue nocturnas, siue cotidianas, siue secundarias, siue tercianas, siue quartanas, siue siluanas, siue iudeas, siue hebreas, uel qualicunque genere sitis, adiuro uos per patrem [...], ut non habeatis licentiam nocere huic famulo dei nec in die nec in nocte, nec uigilanti nec dormienti, nec in ullis locis. ${ }^{2 \mathrm{~T}}$

I conjure you, shivers and fevers - who are seven sisters - like the midday ones, the nightly, the daily, the bi-daily, the three-daily, the four-daily, the wood fevers, the Jewish fevers, the Hebrew fevers, or whatever sort you are: I conjure you through the Father [...], so that you may not have leave to harm this servant of God by day or night, neither waking nor sleeping, nor in any place.

The long incantation goes on further below:

Epistula contra frigores. In nomine de patris [...] Coniuro uos frigores, VII sorores, una dicitur klkb, alia rfstklkb, tertia fbgblkb, quarta sxbfpgllkb, quinta frkcb, sexta kxlkcb, septima kgncb; 
coniuro uos, de quacunque natione estis, per patrem et filium et spiritum sanctum [...] per has omnes inuocationes, coniuro uos, frigores et febres, ut non habeatis ullam licentiam, nocere buic famulo dei N. nec eum fatigare, sed redeatis, unde uenistis, nec potestatem habeatis nec locum in isto famulo dei amen. ${ }^{22}$

Letter against shivers. In the name of the Father [...] I conjure you shivers, seven sisters, the first one called klkb, the other rfst$\mathrm{klkb}$, the third fbgblkb, the fourth sxbfpgllkb, the fifth frkcb, the sixth kxlkcb, the seventh kgncb: I conjure you, of whatever origin you are, through the Father and the Son and the Holy Spirit [...] through these invocations I conjure you, shivers and fevers, so that you do not have leave to harm the servant of Christ N. nor torture him, but return to where you came from, so that you have no power nor a place in this servant of God. Amen.

The second version of the invocation uses a cryptographic method to encode the names of the Seven Sisters, but the code used is a very simple one and can easily be deciphered if one replaces every vowel with its preceding letter: ${ }^{23}$ Ilia, Restilia, Fagalia, Subfogalia (recte: Subfogllia), Frica, Iulia, Ignea (recte: Ignca) in the Vatican text. A Danish formula from the $5^{\text {th }}$ century calls them Illia, Reptilia, Folia, Suffugalia, Affrica, Filica, Loena vel Igne, which gives a very similar result. ${ }^{24}$ However, as the spelling of the names on the Blæsinge tablet is extremely deviant from any other text, we cannot really supplant the two missing names there, although Iulia and Ignea are the ones most obviously absent.

However, the demonic Seven Sisters are certainly not only known from the Blæsinge amulet and the manuscripts mentioned above, but seem to be far more common in Medieval Europe than that. Several British manuscripts from the later Middle Ages and even Early Modern Times mention their names, and also give some of their uses.

In the British Library manuscript MS Sloane 3853 , I43v ( $16^{\text {th }}$ century), the "septem sorores" are mentioned, but only six names given, namely: "lilia, Restilia, Foca, Affrica, Iulia, Iuliana." Here, this is called a charm for "expulsion of elves and fairies", and as such refers only to the conjuration, but not to its purpose. For this period, one may add the manuscript MS. Xd 234 (ca. I600) from 
the Folger Shakespeare library, Washington D.C., giving their names as Lilia, hestillia, fata, sola, afrya, Africa, Iulia, and venulla (variant: Venila), which ventures a magic spell to conjure up the Seven Sisters of the Fairies and tie them to you for ever!25

Another, even later magical $I 7^{\text {th }}$ century manuscript (British Library Sloane 3825$)$ names them as "Lillia, Restilia, Foca, Tolla, Affrica, Julia, Venulla.” As for their function, the similarly magical British Library Manuscript Sloane Ms I727, 23v ( $7^{\text {th }}$ century) calls upon them like that:

I conjure you sps. or elphes which be 7 sisters and have these names. Lilia. Restilia, foca, fola, Afryca, Julia, venulia [...] that from hensforth neither you nor any other for you have power or rule upon this ground; neither within nor without nor uppon this servant of the liveing god.: $\mathrm{N}$ : neither by day nor by night $[. ..]{ }^{26}$

This wording is, of course, very closely related to both the Schleswig and the Halberstadt texts and shows that such beliefs were still known in Early Modern times, but none mentions any illnesses and none of them is as detailed as the Vatican manuscript mentioned above which must, therefore, remain our main guide. The wording in this manuscript shows that the missing words on the Blaesinge amulet must have referred to those frigores et febres ("shivers and fevers") mentioned in both versions in this manuscript.

From the detailed description, however, we learn a lot about the seven sisters which does not become clear from the Blæsinge amulet alone: I. The Seven Sisters are demons for various types of fevers and are individually named, but neither the names nor their numbers bear any direct relationship to the nine types of fevers enumerated in the text. 2. The Seven Sisters are supposedly of different origin (the text says "nation", which refers to geographical direction rather than ethnicity). 3. The aim of the invocation is twofold, firstly to deprive the sisters of their power to harm and secondly to send them back to where they came from.

The earliest instance of the invocation of the Seven Sisters (as seven fevers) is apparently an eleventh-century charm attributed to Saint Sigismund, the so-called Sigismund charm. ${ }^{27}$ This refers to King Sigismund of Burgundy, murdered in 523, and early on 
considered to be useful for invocations against fevers, whether by masses read to call on him or the charm. It is found in a Latin manuscript from Dijon, Bibliotheque municipiale 448 , fol. I $8 \operatorname{Ir}^{28}$ fol, addressing them as follows: "I conjure you, $\mathrm{O}$ fevers, you are seven sisters", followed by their names Lilia, Restilia, Fugalia, Suffoca, Affrica, Julia, Macha. ${ }^{29}$

Although the names of the Seven Sisters are far from stable in the transmission, at least in the Early or High Medieval texts they are clearly considered to be seven fever-demons; but as the first of the incantations in the Vatican manuscript names all sorts of fevers, there is no reason to believe that either the incantations or the Blæsinge amulet or any of the others are only specifically aimed at malaria, as Stoklund ${ }^{3 \circ}$ and Düwel ${ }^{31}$ seemed to think, although malaria was known in medieval Northern Europe simply because of the much warmer climate then. ${ }^{32}$

A detailed list of fevers in the context of an invocation is contained in another Vatican manuscript, Cod. Lat. Vat. 5 I0, I68r, dating from the $\mathrm{I}{ }^{\text {th }}$ century and probably originating in the French Premonstratensian Abbey of Clairefontaine in Picardy. ${ }^{33}$ It certainly was too long to ever have been used on an amulet, but it shows to what extreme detail and completeness a formula for an incantation was able to go to by naming an incredible number of saints, angels and names of God. ${ }^{34}$ Despite the fact that it does not name any fever demons, it gives a list of the various types of fevers concentrating to the recurrent types of fevers or malaria:

† In nomine domini nostri Jhesus Christi coniuro uos febres cotidianas, biduanas, triduanas, quartanas, quintanas, sextanas, septanas, octavas, nonas usque ad nonam graduationem, ut non habeatis potestatem super hunc famulum dei .N. ${ }^{35}$

† In the name of our Lord Jesus Christ I conjure you daily fevers, bidaily fevers, three-daily fevers, [...] nine-daily fevers, up to the ninth graduation, so that you may not have power over this servant of God N.N.

It seems therefore that the observation made from the description of body parts on the Blaesinge and Romdrup amulets holds true: that it is indeed some general infection, which was only identified by its main symptoms - fever and cold shivers. Such infections 
belonged, right up to the late $19^{\text {th }}$ century, to the most enigmatic illnesses, especially those with regularly recurrent fever attacks. This is not without good reason, as feverish infections may be caused by viruses (as influenza, three-day fevers/Roseola infantum, measles and rubella), by bacteria (as in some cases of influenza), or parasites (as with malaria). As none of these sources have any clear or visible reasons, the assumption of demonic origin is obvious. Thus, to look for demonic help or ways of controlling the demonic forces was an obvious way of dealing with them, and this is what our amulets attempt to do.

\section{Notes}

I. Simek 20II; 20I3; 2017.

2. Cf. Kormáks saga Ch. 22.

3. Cf. Stoklund 2003.

4. Imer 20I 5:I4-I 5.

5. Cf. Muhl 2013.

6. Sørheim 2004:2 I3-2I4.

7. Cf. McKinnel et al. 2004.

8. Joh. I, I-I4.

9. Imer \& Uldum 201 5:I 2.

IO. Joh. I, I.

I I. Düwel 200I; Simek 20II.

I2. Gastgeber \& Harrauer 200I; Düwel 200 I.

I3. Steenholt Olesen 2010:I72.

I4. The recently found and as yet unpublished lead amulet from Svendborg is the third such text from Denmark with an identification of demons and álfar, after the Romdrup and Schleswig amulets. The equation on the Halberstadt cross of a certain Alber with Satan can be added to these.

I 5. Steenholt Olesen 2010:I72. 
I6. E.g. Æbelholt-blyamulet Sj I I; Vokslev-blyamulet NJy 57; Køgeblyamulet Sj I4. See http://runer.ku.dk/Search.aspx (as of $\mathrm{I}^{\text {st }}$ Feb. 20I6).

I7. Cf. the close comparison of textual units in Düwel 200 I.

I8. Düwel 200I:243.

I9. Stoklund I986:207-208.

20. Franz I909 II:483; cf. also Simek 20I I.

2. Codex Vaticanus Latinus 235.

22. Codex Vaticanus Latinus 235.

23. Cf. Düwel 2003:243.

24. Ohrt I9I7-I92I II:II43.

25. I am grateful to Joseph H. Peterson for pointing out the Sloane and Folger manuscripts to me.

26. Briggs I959:250-25I.

27. Wallis 2010:69.

28. Wickersheimer 1966:32-33.

29. Whether the medieval tradition of the demonic Seven Sisters goes back to the pseudo-epigraphic Testament of Solomo $\left(4^{\text {th }}\right.$ century), where seven sisters of demons are named, and these in turn originally referred to the seven Pleiades of Greek mythology (but they were called Alkyone, Asterope, Ceaeno, Elektra, Maia, Merope, Taugete, which have absolutely no reflection in the medieval names), or else to the Biblical statement that Jesus had driven out seven demons from the body of Mary of Magdala (Luc. 8,2: Maria, quae vocatur Magdalene, de qua septem daemonia exierant), or even have something to do with the legend of the Seven Sleepers (Septem dormientes) still needs further investigation for which this is not the place.

30. Stoklund I986:204-207.

3I. Düwel 200I:243.

32. Cf. also Schmid I904. 
33. Schmid I904:296-297.

34. Cf. Simek 20 I I.

35. fol. I68v; Schmid I904:208.

\section{References}

Briggs, Katharine Mary. 1959. An Anatomy of Puck. An Examination of Fairy Beliefs among Shakespeare and his Contemporaries. London: Routledge \& Kegan Paul.

Düwel, Klaus. 200I. Mittelalterliche Amulette aus Holz und Blei mit lateinischen und runischen Inschriften. In V. Vogel (ed.). Ausgrabungen in Schleswig. Berichte und Studien I5. (= Das Archäologische Fundmaterial II), Neumünster: Wachholtz, 227-302.

Franz, Adolph. I909. Die kirchlichen Benediktionen im Mittelalter. 2 Vols., Freiburg i.B.: Herder.

Gastgeber, Christian \& Harrauer, Hermann. 200I. Ein christliches Bleiamulett aus Schleswig. In V. Vogel (ed.) Ausgrabungen in Schleswig, Berichte und Studien I5 (= Das archäologische Fundmaterial II), Neumünster: Wachholtz, 207-226.

Imer, Lisbeth M. \& Uldum, Otto C. 20I5. Mod dæmoner og elverfolk. In Skalk 20I 5, 9-I 5 .

McKinnel, John \& Simek, Rudolf \& Düwel, Klaus. 2004. Runes, Magic and Religion. A Sourcebook. Vienna: Fassbaender.

Muhl, Arnold \& Gutjahr, Mirko. 2013. Magische Inschriften in Blei. Inschriftentäfelchen des hohen Mittelalters aus Sachsen-Anhalt. Halle/S.: Landesamt für Denkmalpflege Sachsen-Anhalt (= Kleine Hefte zur Archäologie Sachsen-Anhalt Io).

Ohrt, Friedrich. I917-I92 I. Danmarks Trylleformler. Vol. I: Inledning og tekst. Kopenhagen/Kristiania: Gyldendal. Vol. II: Efterhøst og Lönformler. Kopenhagen/Kristiania: Gyldendal.

Schmid, Ulrich. I904. Malariabenediktionen aus dem XII. Jahrhundert. In Römische Quartalschrift I 8, 205-2 I0. 
Simek, Rudolf. 20I I. Elves and Exorcism. Runic and Other Lead Amulets in Medieval Popular Religion. In D. Anlezark (ed.). Myths, Legends and Heroes. Essays on Old Norse and Old English Literature in Honour of John McKinnell. Toronto: University of Toronto Press, 25-52.

Simek, Rudolf. 2013. Álfar and Demons, or: What in Germanic Religion Caused the Medieval Christian Belief in Demons? In R. Simek \& L. Slupecki (eds.). Conversion. Looking for Ideological Change in the Early Middle Ages. Vienna: Fassbaender (= SMS 23), $32 \mathrm{I}-342$.

Simek, Rudolf. 20I 7. “On Elves”. In S. Brink \& L. Collinson (eds.). Theorizing Old Norse Myth. Turnhout: Brepols, I95-223.

Steenholt Olesen, Rikke. 20I0. Runic Amulets from Medieval Denmark. In Futhark. International Journal of Runic Studies I (20I0), I6I-I76.

Stoklund, Marie. I984. Nordbokorsene fra Grønland. In Nationalmuseets Arbejdsmark I984, IOI-II3.

Stoklund, Marie. I986. Runefund. In Aarbøger for Nordisk Oldkyndighed og Historie 1986, I 89-2 I I.

Stoklund, Marie. 2003. Bornholmske runeamuletter. In W. Heizmann \& A. van Nahl (eds.). Runica - Germanica - Mediaevalia (= Ergänzungsbände zum RGA 37). Berlin: de Gruyter, 854-870.

Sørheim, Helge. 2004. Lead Mortuary Crosses Found in Christian and Heathen Graves in Norway. In Medieval Scandinavia I4, I95-227.

Wallis, Faith. 20Io. Medieval Medicine. A Reader. Toronto: University of Toronto Press.

Wickersheimer, Ernest. 1966. Les manuscrits latins de médecine du haut Moyen Age dans les bibliothèques de France. Paris: Centre national de la recherché scientifique. 


\section{Response}

Olof Sundqvist

Stockholm University

During the last decades several important scholarly works on medieval magic in Scandinavia have been published, such as Catharina Raudvere's Kunskap och insikt i norrön tradition, ${ }^{\mathrm{I}}$ François-Xavier Dillmann's Les magiciens dans l'Islande ancienne, ${ }^{2}$ and Stephen A. Mitchell's Witchcraft and Magic in the Nordic Middle Ages. ${ }^{3}$ Different themes related to magic in everyday life are treated there, for instance romance, fortune, weather, malediction, health and disease. In his contribution to the present book, "Tangible Religion: Amulets, Illnesses, and the Demonic Seven Sisters", Rudolf Simek concentrates on this latter aspect, or more precisely, the apotropaic methods of coming to terms with illnesses in medieval Northern Europe, such as magic charms, amulets, and rituals. These strategies may, according to Simek, have their background in the pre-Christian Germanic religion, although they may also derive from the Mediterranean regions. Some of them may even have had a mixed background; such syncretistic expressions are usually called "medieval popular religion".

In previous studies Simek has investigated the role of the mythical beings called Old Norse álfar (Latinised elvos, elvas etc.) in medieval popular religion. ${ }^{4}$ During the Middle Ages these beings were regarded as demons of illness. Amulets and charms were used to ward off their harmful activities and by means of magical-religious methods the causes of the diseases were believed to be removed. In the Old Norse poetic tradition, which may reflect the Viking Age conception of the álfar, these spiritual beings, were not primarily considered to be demonic. In the Viking Age context, they were probably regarded as divine beings beside the cesir, who could be helpful to humans. In the present study Simek is concerned not only with the alfar, but also with other beings related to illness in medieval popular religion, particular 
the demons called "the seven sisters" (in Latin septem sorores). Simek focuses his investigation on six Latin texts (charms) written on amulets, where such beings are mentioned. Four of them are from Denmark, where two were written with runes and two with Latin letters. The other two amulets are from Germany and they were written with Latin letters. All of them are dated to the period IOOO-I 400 .

The purpose of Simek's investigation is firstly, to "look into the types of protection from illnesses named on the amulets" and secondly "to ascertain whether there is any relation between the protection requested and the types of demons conjured". In order to implement these aims Simek compares the amulet texts with some Latin manuscripts, also concerned with illness demons and magic charms. The seven sisters (the illness demons) mentioned in the Blæsinge amulet from Denmark (c. I 200-I 400), for instance, and also appearing in the Latin manuscripts, are probably related to different types of fevers. They are described with individual names; however, neither the number of them, nor their names have a direct relationship to the fevers described. According to the medieval manuscripts, the demons originates from different places. The aim of the invocations is to deprive the sisters of their power to harm and to send them back to where they belong. Also, the six amulet texts analysed by Simek probably include similar purposes.

In what follows I will only discuss one aspect of Simek's interesting contribution. In his study, Simek deals with the phenomenon called syncretism, and specifically what happens with old mythical conceptions and beings when they are set in new religious contexts. Some of the demons in Simek's text corpus are called Latin Elvae, Elves, Albes, and Alber. In the Schleswig lead amulet (c.IO00-IIOO), for instance, we may read in $\mathrm{C}_{3}$ : c(on)iuro vos demones sive albes ac om(ne)s pestes om(n)iu(m) infirmitatu(m) "I conjure you, demons and elves, and all the infections of illness, and ...". ${ }^{5}$ It seems thus as if the Albes (ON álfar), in their new medieval context have been revaluated; they have changed their character from being spirits with positive aspects for humans to demons causing illness. This demonization of mythical beings is 
not consistent when it comes to the total corpus of the early medieval amulet texts involving protection against diseases. There are examples where pre-Christian mythical beings have preserved their power of protecting against demons of illness in their new medieval context. Pórr, for instance, appears in the text on the Kvinneby amulet from Öland, usually dated to the early I I $^{\text {th }}$ century, but recently re-dated to I050-I I $30 .{ }^{6}$ This text is carved with runes in native language. According to Jonna Louise-Jensen, ${ }^{7}$ we may read in one sequence:

\section{porketih ansmiRpemhamrisamhyR ...}

Pōrr gāeti hans mèr pēm hamri (e)s Ām hyRR ...

May Pórr guard him [Būfi] with the hammer with which he strikes $\bar{A} m r($ a giant $=$ the demon $) \ldots$

According to Louise-Jensen, Pórr here protects the sick man Būfi (who is mentioned earlier in this inscription) with his hammer against the giant Āmr who has caused his skin disease (erysipelas). ${ }^{8}$ In my opinion it is quite possible that the carver of this inscription at least in part is set in a pre-Christian universe of ideas. Āmr might very well be related to (or identical with) the mythical giant Ímr, as mentioned in Váfprúðnismál st. 5. The motif that Pórr hits giants with his hammer is often found in Old Norse mythic traditions. ${ }^{9}$ Some of these traditions are also referred to in a couple of skaldic stanzas containing some kind of liturgical texts (recollections of hymns or prayers) where Pórr is addressed as "you" who killed "NN". ${ }^{\text {Io }}$ It is thus likely that the carver alluded to this famous mythic motif as he carved the copper sheet, or perhaps to a specific myth, when he mentioned that Pórr protected with his hammer, that is, the hammer that broke Āmr (or Ímr). This does not have to exclude that the inscription is also about a cure or a type of folk medicine, where Būfi is the patient, and Āmr is the giant/demon that caused his skin disease. The fact that Pórr was invoked for protection against disease is found in other texts referring to pre-Christian contexts. According to Adam of Bremen, ${ }^{\text {II }}$ the Svear sacrificed to Pórr if plague and famine threatened (Sipestis et fames imminet, Thor ydolo lybatur). The Kvinneby amulet 
may thus include an old prayer formula for divine assistance to whoever carried this ritual object. There are, however, images on this amulet indicating that the person who used it was between two universes of beliefs. The fish, for instance, is most likely a symbol of Christ as the Saviour. The whole amulet could thus be seen as an expression of religious syncretism..$^{\text {I2 }}$ In my opinion the Kvinneby amulet, which is carved with runes in a native language is thus in some sense closer to a pre-Christian context, than the amulets carved in Latin. Even if on this amulet Pórr is set in a new medieval and Christian context, he has not yet changed to be identified as a demon causing illness, as, for instance, the elves (álfar) mentioned in the Schleswig amulet text. It seems thus as if the first generations of Christians on the island of Öland, at least occasionally, still used the old religious-magical formula when curing illness. Some of them included ancient mythical themes, where the old divinities continued to act as protectors.

\section{Notes}

I. Raudvere 2003.

2. Dillmann 2006.

3. Mitchell 20I I.

4. Simek 20II; 20I3.

5. McKinnell et al. 2004:I 53.

6. Pereswetoff-Morath 2017:143.

7. Louise-Jensen 2005.

8. cf. e.g. McKinnell et al. 2004:65-67; Düwel 2008:136; and most recently Pereswetoff-Morath 2017:106-I 43.

9. Lindow 200I:287-29I; Simek 2006:2 I9, 3 I6-326.

ıо. See e.g. Vetrliði Sumarliðason's lausavísa in Skj Bı:I27; Aı:I35; Pórbjǫrn dísarskáld in Skj BI:I3 5; AI:I44; cf. Jackson 2005:492.

I I. Adam of Bremen IV, 27.

I 2. Cf. Hultgård I 988: I43. 


\section{References}

\section{Primary sources}

Adam of Bremen. Magistri Adam Bremensis Gesta Hammaburgensis Ecclesiae Pontificium. Scriptores rerum germanicarum in usum scholarum. Ex Monumentis Germaniae Historicis. Editio Tertia. Red. Bernhard Schmeidler. I9I7. Hanover-Leipzig: Hansche Buchhandlung.

Den Norsk-Islandske Skjaldedigtning. Finnur Jónsson. 1967-1973 (I9I2-I9I5). Den Norsk-Islandske Skjaldedigtning 800-I400. AI-2, BI-2. Ed. Finnur Jónsson. København: Rosenkilde og Bagger.

\section{Secondary literature}

Dillmann, François-Xavier. 2006. Les magiciens dans l'Islande ancienne, Acta Academiae regiae Gustavi Adolphi. XCII. Uppsala: Kungl. Gustav Adolfs Akademien för svensk folkkultur.

Düwel, Klaus. 2008 (I968). Runenkunde. 4. Auflage. Weimar: J.B. Metzler.

Hultgård, Anders. 1988. Recension av Lindquist 1987. In Svenska landsmål och svenskt folkliv, I37-I45.

Jackson, Peter. 2005 . Thorsmythen. In H. Beck et al. (eds.). Reallexikon der Germanischen Altertumskunde. 2. Aufl. Band. 30. Berlin, New York: de Gruyter, 490-498.

Lindow, John. 200I. Norse Mythology. A Guide to the Gods, Heroes, Rituals, and Beliefs. Oxford: Oxford University Press.

Louise-Jensen, Jonna. 2005. Södra Kvinneby. In H. Beck et al. (eds.). Reallexikon der Germanischen Altertumskunde. 2. Aufl. Band 29. Berlin, New York: de Gruyter, I94-I95.

McKinnell, John; Simek, Rudolf \& Düwel, Klaus. 2004. Runes, Magic and Religion. A Sourcebook. Studia medievalia septentrionalia. Io. Wien: Verlag Fassbaender.

Mitchell, Stephen A. 20 I I. Witch craft and Magic in the Nordic Middle Ages. The Middle Ages Series. Philadelphia, Oxford: University of Pennsylvania Press. 
Pereswetoff-Morath, Sofia. 2017. Vikingatida runbleck. Läsningar och tolkningar. Uppsala: Institutionen för nordiska språk, Uppsala Universitet.

Raudvere, Catharina. 2003. Kunskap och insikt $i$ norrön tradition. Mytologi, ritualer och trolldomsanklagelser. Vägar till Midgård 3. Lund: Nordic Academic Press.

Simek, Rudolf. 2006 (I993). Dictionary of Northern Mythology. Orig. titel: Lexikon der germanischen Mythologie. Cambridge: D.S. Brewer.

Simek, Rudolf. 20I I. Elves and Exorcism. Runic and Other Lead Amulets in Medieval Popular Religion. In D. Anlezark (ed.). Myths, Legends and Heroes. Essays on Old Norse and Old English Literature in Honour of John McKinnell. Toronto: University of Toronto Press, 25-52.

Simek, Rudolf. 2013. Álfar and Demons, or: What in Germanic Religion Caused the Medieval Christian Belief in Demons? In R. Simek \& L. Slupecki (eds.). Conversion. Looking for Ideological Change in the Early Middle Ages. Vienna: Verlag Fassbaender, $32 \mathrm{I}-342$. 
